\title{
AIRCRAFT IN FIGHT WITH IRREGULAR FORCES IN THE FIRST DECADE OF THE 21ST CENTURY
}

\begin{abstract}
It cannot be denied that the difference in the fight against irregular forces, which results from the non-standard operation of these forces, as well as the role played by the civilian population in this fight, have a significant impact on the state's definition of the conventions of its conduct. Many years of experience prove that the state's struggle with irregular forces is not only a very complex issue, but also a particularly difficult one to implement. Against this background, this study focused on empirically examining the use of aircraft (and the goal of its use) in combat with irregular forces. It also assessed problems that arise in aviation combat with irregular forces, while offering insights on the use of aviation in the fight against irregular forces. The research used document research as well as quantitative and qualitative analysis as its methods, and a systematic review of scientific literature on the use of aviation in the fight against irregular forces was conducted. The results of the research show that the fight in question requires the armed forces' use of aircraft/aviation in organized combat and non-combat operations. However, one should be aware that aviation has its specific attributes, and it should not be prioritized over other means of combat, as it is insufficient to defeat irregular forces in a short time, alone, or even jointly with other military components.
\end{abstract}

Keywords: armed forces, aviation, irregular warfare, irregular forces.

\section{INTRODUCTION}

Air safety covers various issues, depending on the category of entities, located at different levels of the analysis. The Russian annexation of the Ukrainian Crimea (March $18,2014)$, followed by the outbreak of the Kremlin-inspired rebellion in the south-east of Ukraine, actively supported by raids of regular and irregular Russian troops, necessitates a broader look at air security (Fryc, 2015). At the same time, the experts' attention was drawn to a new form of security threat, which is irregular armed aggression below the threshold of open war (Fryc, 2015). This form, hailed as a hybrid war, turned out to be a serious challenge for state authorities, the reactivity of defense systems and the decision-making power of international security institutions.

\footnotetext{
${ }^{1}$ Grzegorz Rosłan, DSc, PhD, Associate Prof., The Faculty of Management, Rzeszow University of Technology, 35-959 Rzeszów, al. Powstańców Warszawy 12; e-mail: g.roslan@prz.edu.pl. ORCID: 0000-0002-2566-5004.
} 


\section{AVIATION AGAINST IRREGULAR FORCES - AFGHAN EXPERIENCES}

The disintegration of the political and military blocs and the socio-political changes gave hope for international security. However, it soon turned out to be a deceptive feeling. The first decade of the 21 st century revealed many contradictions and tensions that led to the escalation of threats to security in the local, regional and even global dimensions. The breakthrough year was 2001, when irregular forces launched an attack on the World Trade Center and the Pentagon. The international community decided to send military forces to fight irregular forces.

The end of the Russian intervention did not mean peace for Afghanistan at all. Post-war Afghanistan was actually only formally a state. In practice, it consisted of a dozen completely independently functioning entities, gathered around tribal leaders with considerable military power. The economy of these entities was based on incomes usually derived from illegal sources - primarily drug trafficking. Afghanistan's deteriorating internal situation was used by a fundamentalist Islamic group (the Taliban), which quickly gained considerable public support. The Taliban owed their successes to an innovative strategy of combining propaganda and force, ensuring the efficient restoration of peace in the occupied territories. By the end of the $1990 \mathrm{~s}$, the Taliban controlled nearly $90 \%$ of Afghanistan's territory (Maley, 2002). The Taliban's march for absolute power in Afghanistan was interrupted by the tragic events that took place in 2001. "One day after the tragedy, President G.W. Bush has received reports that quite clearly indicate al-Qaeda and the Afghan Taliban as the perpetrators and protectors of the attacks" (Reginia-Zacharski, Łoś, 2010). Based on the evidence at hand, the US decided to send an ultimatum demanding, inter alia, "handing over to the US authorities all al-Qaeda leaders and those involved in terrorist activities and supporting them, who were in Afghanistan, and the immediate and final closure of all terrorist training camps in Afghanistan" (Reginia-Zacharski, Łoś, 2010).

The ultimatum by the then Afghan authorities was rejected. In view of the above, the US and other NATO countries have become convinced that it is impossible to solve the Afghan issue through diplomatic channels and that it is necessary to use military forces. The use of armed forces by the international community has been confirmed by the relevant UNSC resolutions.

The first to enter the fight were special forces, which for some time had been penetrating the territory of Afghanistan in search of objects of attack. After the decision to use aviation, their task was also to guide air bombs and missiles at detected Taliban positions and the objects they occupied. The aviation precision weapons used amazed not only the Taliban and their allies. There was even a belief among Afghan allies of the USA that "the lasers used by the special forces to point at the targets of the air raids were some kind of death beams, as any outpost on which they fell would soon disappear" (Baylis, 2009). The air force carried out many attacks on its own, without the help of special forces. However, before it was decided to launch an independent attack from the air, the suspicious objects were first verified using reconnaissance means located in space. Positive verification triggered the take-off of planes - due to the lack of land bases at that time, all planes, apart from bomber planes, took off from aircraft carriers sailing off the Pakistani coast - and from maneuvering missiles with the task of making a precise attack.

The significant weakening of the Taliban by air attacks made it possible to begin cleaning the territory of Afghanistan of those forces that still remained. This task was entrusted to the troops of the Northern Alliance, i.e. loosely organized armies of tribal 
leaders supported by the air force of the multinational task force. Air force officers cooperating with commanders of the Alliance's forces were responsible for detailed planning and coordination of aviation activities. The scope of air support concerned reconnaissance, direct fire impact and transport. Precision weapons were used wherever it was justified. Even supplies were thrown using Precision Airdrop Systems (PADS). In this way, food and medicine were also provided to the needy civilians (Leśnikowski, 2007).

After two months of intense frontline fighting, the Taliban was deemed to have suffered heavy casualties, and the rest had either dispersed or taken refuge in Pakistan. The authorities in Afghanistan were taken over by the interim government of H. Karzai. The multinational task force could therefore move on to stabilization activities related to the maintenance of order in this unstable country and the support of a democratically elected government.

"From 2003, the Taliban began to take root again in Afghanistan, and over the years their insurgency spread step by step across the country" (Giustozzi, 2009). The actions of small, a dozen or so combat units of irregular forces freely moving around Afghanistan, destabilizing the situation in the country, have become a practice. The growing activity of these formations showed that the trumpeted victory in the fight against the Taliban and their allies was illusory. This time, the opponent of the multinational task force, in addition to the Afghan Taliban - poorly trained and primitive in the tactics used, were mercenaries from other Muslim countries - better trained and more determined in combat and best prepared to fight - terrorists who passed through al-Qaeda training camps. In mid-2010, over 100,000 people faced each other in the Afghan theater of operations. soldiers of NATO countries with the most modern aviation ever used in a war, supported by tens of thousands of soldiers of the local army and 25 thousand irregular forces without aviation and only to a limited extent anti-aircraft weapons (Creveld, 2013).

The air force delegated to fight irregular forces was tasked with ensuring the continuity of deep-sea operations, direct support of land forces and the mobility of multinational task forces (Bartnik, 2009). By carrying out deep operations in areas controlled by irregular forces, the irregular aviation obtained information about their activity and had a fire effect, whenever there was an opportunity. For the search and tracking of irregular forces, unmanned aerial vehicles were primarily separated (LeHew, Collins, 2010). The optoelectronic and infrared devices with which the unmanned aerial vehicles were equipped gave reliable identification even if the irregular forces were well masked. The position of the located enemy in near real time was transferred to the zone's on-duty duty planes, also at night, of attack planes or armed transport planes. Having taken a convenient position, the crews of these planes immediately launched an attack. The cooperation between the aircraft operators of the ground observation system from the air and the crews of attack aircraft was similar. The crews of the latter, after reaching the short-term waiting zone, established radio communication with the aircraft of the ground observation system from the air circulating in a safe orbit. The aircraft operators of the ground observation system from the air indicated a specific object to be destroyed by transmitting its coordinates. When, within several dozen minutes, the attack aircraft crews did not receive an attack object, they were directed to a pre-designated zone (along the strategic communication route), where they searched and fought the enemy on their own (Gotowała, 2003). In order to ensure the continuity of the use of aviation, in this way, airplanes were used for refueling in the air.

Despite the significant involvement of the unmanned and manned aviation, the irregular forces operating in the depths of operation managed to avoid destruction. As soon as the 
noise of the incoming air force formation was heard, the irregular force immediately divided into small groups that hid in the field. Hiding in the neighborhood was not always easy, especially for those groups who came from other territories. The ability to convert the time needed, for example, by helicopters to fly from an air base over irregular forces positions, was useful. In many cases, the arriving helicopters became useless as the target of the attack was no longer there (Giustozzi, 2009). The improvement took place after the introduction of unmanned aerial vehicles in the armed version, which, imperceptibly for irregular forces, detected them and began to destroy them immediately.

Due to the possibility of losses among own troops during the execution of direct support, efforts were made to provide the crews of attack aircraft with full situational awareness. The desired state was achieved through continuous duty in the designated zone of unmanned aerial vehicles and visualizing the position of own troops on the aircraft. Marker radios and electronic identifiers were helpful in the visualization. Moreover, each attack on the enemy object located in close proximity to own troops was carried out with the use of a precise means of destruction and was carried out under the supervision of a guidance navigator. However, when there was a fear of undesirable losses among the civilian population, attacking the enemy's object, it was decided to use precise measures with reduced firepower. Whenever it was tactically justified, the planes flew over irregular force positions while firing thermal traps (force show) (Cordesman, 2008). At that time, they counted on the awareness of the attacked irregular forces so that they would stop fighting, under the threat of returning and dropping their weapons.

A common practice for direct support was an air escort of a moving combat patrol or military convoy. The escort was carried out by forces of a specially created unit of ground forces, the so-called task forces (TFODIN - Task Force Observe, Detect, Identify and Neutralize). The task force included, inter alia, unmanned aerial vehicles and light turboprop airplanes equipped with video cameras and electronic reconnaissance sensors. These aircraft operated in a uniform system with brigade commanders and crews of combat helicopters, which neutralized the threat relatively quickly. The activity of irregular forces suspected of placing improvised explosive devices (IEDs) was monitored by analysts working on board the aircraft and unmanned aerial vehicle operators in the headquarters of the task force (Glass, 2009).

Although the introduction of task forces to combat irregular forces shortened the time from the detection of the threat to its elimination, it did not ensure complete safety for combat patrols or military convoys. Irregular forces conducting the actions took care to have direct communication with informants around the air base who sent them a signal about the departure of the combat helicopter. After receiving the signal, the irregular forces immediately dispersed and hid in previously prepared hiding places, making them difficult to find without the participation of additional ground forces.

The mobility of the multinational task force operating in the Afghan theater of operations (Afghanistan has no access to the sea and a poorly developed road system) required significant aviation involvement (Cordesman, 2008). Transport in the strategic dimension - between the place of permanent deployment of the military contingent and the theater of operations - was carried out by long-range transport aircraft, many of which were borrowed or leased from civilian carriers. However, due to the fact that civil aircraft were too demanding in terms of airport infrastructure and costly to endanger them, they transported soldiers and equipment only to a neighboring country that agreed to cooperate. From there, the transfer to Afghanistan was done in smaller military transport planes. 
Removal of the wounded and soldiers whose shift has ended was performed in the reverse order. On the other hand, transport in the tactical dimension - in the theater of operations was provided by helicopters, which efficiently and quickly transported units of the ground forces to the most distant places, where the fight against irregular forces was carried out.

After the end of the frontline combat, aviation was also active - albeit to a lesser extent - in conducting electronic warfare. Subsequent US military contingents to Afghanistan always carried a key electronic warfare aircraft that carried out at least one mission a day, seven days a week. In addition to the typical missions to disrupt communication systems used by irregular forces, airplanes conducted radio reconnaissance. The crew included not only electronic system operators, but also listening system operators - linguists who analyzed the intercepted radio correspondence on an ongoing basis (Knowles, Goodman, 2007). Noteworthy was the collaboration of aircraft conducting electronic interference with the aircraft intended for psychological activities focused on broadcasting radio broadcasts.

Since the beginning of the war in Afghanistan (as was the case in Iraq), US troops lacked flexible real-time communication. Ground force units had a problem communicating with combat aircraft, flying command centers or reconnaissance aircraft. This was due to the use of various tactical data links, communication protocols, and radio wavebands. Of course, satellite communication was a remedy, but it works with a certain delay, which in many cases determined the life of soldiers on the ground. The solution to the problems came with the development of the Battlefield Airborne Communications Node (BACN), which automatically translated various communication protocols. By the end of 2012, aircraft equipped with the BACN system departed nearly 50,000 hours in Afghanistan (Modrzejewska, 2013).

Although there were no airplanes and medium-range anti-aircraft systems on the side of the irregular forces, the aviation of the multinational task forces did not have complete freedom in the airspace. The real threat was posed by portable anti-aircraft systems, the irregular forces of which were in large numbers. Therefore, manned aviation only performed flights at safe altitudes and, in addition, the aircraft were equipped with flare launchers and on-board laser active defense systems. In the event of an immediate threat, the crews of the aircraft reduced the flight altitude below the missile range and increased speed, and if it was not possible to lower the flight, they made a flight with a snake at maximum speed and periodic course changes (Zieliński, 2012).

The problem that was faced, among others, by The US Army in Afghanistan has had significant operating costs for modern jet aircraft. Commanders began to consider introducing to the fight against irregular forces, cheaper to manufacture and operate lightweight turboprop multi-role aircraft and transport aircraft, without limiting the tasks assigned to aviation. These intentions were confirmed by the statement by A. Brookes

that you cannot win in Afghanistan, even by putting at stake all your potential built on the basis of the rules applicable in regular warfare, which is why we are actively opting for the creation of at least two rapid response air units equipped with airplanes with economical engines (AKLOT, 2010). 


\section{AVIATION AGAINST IRREGULAR FORCES - ISRAEL EXPERIENCE}

From the point of view of the issue under investigation, i.e. the use of aviation to fight irregular forces, it is interesting to present another characteristic conflict between Israel and Hezbollah. In the last two decades of the 20th century, Israel went out of its way to combat Hezbollah, an Islamic Shi'ite political party supported and financed by Iran and Syria. He used all available tools, including the use of the armed forces. After each raid on a Hezbollah facility deployed in Lebanon, the spokesman for the Israeli Defense Forces made it public that all of our planes had returned to base, and pilots reported certain hits (Creveld, 2013). Despite the imbalance in combat measures in favor of Israel, Hizbullah's actions, instead of diminishing, intensified to such an extent that in 2000 Israel withdrew its troops from Lebanon. Social dissatisfaction was aroused by the fact that about 1.5 thousand Israeli soldiers died during the fights of that time (Gordon, 1998).

Six years later, after many minor skirmishes, war between Israel and Lebanon seemed inevitable. This time, the Israeli concept of fighting irregular forces assumed the maximum use of air dominance to create an asymmetrical advantage over the enemy, and thus avoiding own losses on land. According to this idea, aviation was to play a major role. Unmanned aviation was tasked with locating irregular forces, and manned aviation was tasked with destroying them after detection.

The Lebanese theater of action is mountainous and covered with vegetation, most of which are forests. A significant part of the human-friendly terrain is occupied by villages located on the slopes of hills, which in many cases serve as training bases for irregular forces. The Palestinian refugee camps played a similar role.

The fight against irregular forces in Lebanon is another experience resulting from the activities carried out in the urbanized area. The irregular forces surprised Israel not only with their excellent preparation, but also with the way they fight. A network of specialized shelters was built for command posts, ammunition stores and hiding places that were almost impossible to detect from the air. The quarters of religious and military leaders were located adjacent to civilian buildings, in densely built-up neighborhoods in Beirut. Some bunkers connected by tunnels reaching several dozen meters into the ground made it possible for many people to stay in them for several weeks without the need to replenish supplies. In the fight, the irregular forces used mainly missile means with which they terrorized the Israeli civilian population (Cieślak, Mróz, 2010).

For the Israeli aviation, this fight was the first in history in which air operations were carried out on a full scale, for 24 hours. per day, seven days a week, with an average of 350 combat flights a day. The air force, having 100 planes and 50 helicopters, performed nearly 15.5 thousand flights, half of which were made at night. Unmanned aerial vehicles were also used intensively (White, 2006). Although thousands of flights were made and enormous amounts of means of destruction were used, in addition to ruining Beirut and the surrounding area and destroying most of Lebanon's transport infrastructure, the degree of defeat of the irregular forces was far from what was expected. If justification can be found for destroying all bridges and many roads, the moot point is the destruction of fuel depots and gas stations. Taking into account the stocks and the lack of the need for maneuvers, it did not matter much for the irregular forces. On the other hand, the lack of fuel combined with interruptions in electricity supply made life difficult for the civilian population, causing a fuel crisis. On the one hand, civilians were forced to flee, and on the other hand, they were 
given the possibility of movement (White, 2006). Among other things, it was for this reason that it was impossible to win the sympathy of the Lebanese community for the actions of Israel.

It was the same with the fight against missiles. The Israeli air force proved ineffective in countering rocket attacks from Lebanon, although a significant portion of long-range missile systems were destroyed. Short-range missile systems proved to be a problem. They were usually hidden inside concrete bunkers, dug into the ground or buried under vegetation. When the firing orders came in, they were raised to the firing position by means of hydraulic jacks. The constant search of potential sites convenient for the dislocation of these launchers did not help. They were almost impossible to locate from the air, and it was even more difficult to destroy them by the crews of high-altitude airplanes (Rubin, 2007). Therefore, contrary to earlier plans, it was decided to introduce land forces into Lebanon. The purpose of the ground forces was not so much to search for and destroy rocket launchers, but to reassure Israelis in a sense of victory, and irregular forces in a sense of defeat (Matthews, 2008).

Days after the UN Security Council approved the terms of the ceasefire, the fighting ended. Unfortunately, the conflict situation has not been resolved. Israel's lack of success in defeating irregular forces should be attributed primarily to a bad doctrine, which did not provide for the involvement of ground forces in direct combat. Irregular forces operating in urban areas were not an easy enemy to defeat only from the air, if only due to the limitations of aviation per se. The above leads to the conclusion that there was a victory for a small paramilitary organization over a regular, strong and modern army, at the same time questioning the views expressed in Israeli politicians as to the high effectiveness of aviation during combat operations.

\section{CONCLUSION}

When talking about new challenges for the air force, it is worth emphasizing the opinions of experts who believe that wars will be fought not only between states, but above all within nations. This is explained by a clear crisis of sovereign states losing their monopoly on violence to various types of non-state entities (irregular forces). It should be noted that in the case of an irregular war, we are dealing with an adversary, usually focused on many smaller non-state entities, which are referred to as irregular forces. Time, space and the support received play a key role in the operation of irregular forces. Moreover, the above factors are determined by the specificity of evaporating conditions in a given area of operation and its surroundings. Thus, space is the key to success in the fight against irregular forces.

The arguments cited allow to state that the specificity and conditions of the fight against irregular forces require deliberate actions in order to eliminate the threat as soon as possible and restore normality in the functioning of the state. The above conditions also determine the component of the armed forces, which may be involved in the fight against irregular forces. At the same time, the international experience to date shows that it is the air force, and especially aviation, that seems to be the key element of this component, which, apart from the forces operating on land, is of the greatest importance for the effective fight against irregular forces. 
Based on the conclusions from the research, it should be concluded that the idea of using aviation to fight irregular forces is not new and was born in the twenties of the last century. Nowadays, in the fight against irregular forces, both manned and unmanned aerial vehicles can be used, which can carry precision weapons. In addition, aviation, thanks to its attributes, can provide continuous performance of tasks throughout the theater of operations and the desired support depending on the stage and place of the confrontation. What's more, aviation is able to simultaneously carry out tasks related to reconnaissance, transport (evacuation) and fire support. It can also carry out information and airspace surveillance activities. With these actions, aviation can not only compensate for the combat deficiencies of other components participating in the confrontation, but also provide them with the advantage necessary to defeat irregular forces. An important issue from the point of view of the discussed issue is to signal the fact that aviation as part of the fire support of the land-based component can carry out activities related to the isolation of the battlefield, which are a derivative of this type of confrontation.

\section{REFERENCES}

Aktualności lotnicze - AKLOT (2010). Warszawa: Instytut Techniczny Wojsk Lotniczych, nr 2.

Bartnik, R. i in. (2009). Założenia operacyjne użycia lotnictwa w walce z siłami nieregularnymi. Warszawa: wyd. AON.

Baylis, J. i in., red. (2009). Strategia we wspótczesnym świecie, Kraków: wyd. UJ.

Cieślak, E., Mróz, P. (2009). Lotnictwo Izraela w wojnie libańskiej w 2006 roku. Zeszyty Naukowe Akademii Obrony Narodowej, nr 2.

Cordesman, A. H. (2008). Air Combat Trends in the Afghan and Iraq Wars. CSIS, 11 March.

Creveld, M. (2013). Era lotnictwa wojskowego, tł. J. Tomczak. Warszawa: Biblioteka Wojskowa.

Fryc, M. (2015). Polska strategia obronności wobec zagrożenia militarnego z elementami wojny hybrydowej. ,Bezpieczeństwo Narodowe”, 2015/I.

Giustozzi, A. (2009). Koran, kałasznikow i laptop. Rebelia neotalobów w Afganistanie. tt. Ł. Müller. Kraków: wyd. UJ.

Glass J.W. (2009). Taking aim In Afghanistan. "C4ISR Journal”, 5 February.

Gordon, S. L., The Vulture and The Snake. Counter-Guerilla Air Warfare: The War in Southern Lebanon, Mideast Security and Policy Studies, July 1998, No. 39, Chapter 3\&4.

Gotowała, J. (2003). Iraqi Freedom - pustynna szachownica. „Przegląd WLOP”, nr 6.

Knowles, J., Goodman, G. W. Jr. (2007). Compass Call - New AEA. “The Journal of Electronic Defense", Vol. 30, No. 5, maj.

LeHew, P., Collins, J. (2010). Unmanned Aircraft Systems in Irregular Warfare. Air Land Sea Bulletin - Irregular Warfare, January.

Leśnikowski, W. (2007). Lotnictwo w operacjach powietrznych. Warszawa: wyd. AON.

Maley, W. (2002). The Afghanistan Wars. London: Palgrave Macmillan.

Matthews, M. M. (2008). We were caught unprepared. The 2006 Hezbollah - Israeli War. US Army Combined Arms Center, Fort Leavenworth.

Reginia-Zacharski, J., Łoś, R. (2010). Współczesne konflikty zbrojne. Warszawa: Wydawnictwo Naukowe PWN.

Rubin, U. (2007). The Rocket Campaign against Israel during the 2006 Lebanon War. The Begin-Sadat Center for Strategic Studies Bar-Ilan University, Israel, June. 
White, J. (2006). Military Implications of the Israel - Hezbollah War [w:] Lessons and Implications of the Israel - Hezbollah War, The Washington Institute, October.

Zieliński, T. (2012). Lotnictwo wojsk lądowych w misjach poza granicami kraju. Warszawa: wyd. AON.

DOI: 10.7862/rz.2021.hss.36

The text was submitted to the editorial office: December 2021.

The text was accepted for publication: December 2021. 
